\title{
Federal Government, Utility, Manufacturer: A Unique Partnership for Comprehensive Water Efficiency
}

Katherine Mayo

National Renewable Energy Laboratory

Prepared for CONSERV 96, sponsored by the American Water Works Association, Orlando, Florida, January 6, 1996

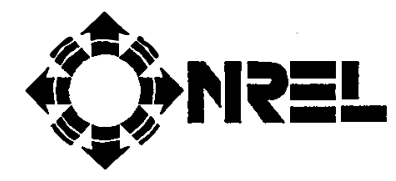

National Renewable Energy Laboratory 1617 Cole Boulevard Golden, Colorado 80401-3393

A national laboratory of the U.S. Department of Energy Managed by the Midwest Research Institute for the U.S. Department of Energy under Contract No. DE-AC36-83CH10093

October 1995 


\section{NOTICE}

This report was prepared as an account of work sponsored by an agency of the United States government. Neither the United States government nor any agency thereof, nor any of their employees, makes any warranty, express or implied, or assumes any legal liability or responsibility for the accuracy, completeness, or usefulness of any information, apparatus, product, or process disclosed, or represents that its use would not infringe privately owned rights. Reference herein to any specific commercial product, process, or service by trade name, trademark, manufacturer, or otherwise does not necessarily constitute or imply its endorsement, recommendation, or favoring by the United States govemment or any agency thereof. The views and opinions of authors expressed herein do not necessarily state or reflect those of the United States government or any agency thereof.

Available to DOE and DOE contractors from:

Office of Scientific and Technical Information (OSTI)

P.O. Box 62

Oak Ridge, TN 37831

Prices available by calling (615) $576-8401$

Available to the public from:

National Technical Information Service (NTIS)

U.S. Department of Commerce

5285 Port Royal Road

Springfield, VA 22161

(703) $487-4650$ 


\title{
Federal Government, Utility, Manufacturer: A Unique Partnership for Comprehensive Water Efficiency
}

\author{
Katherine Mayo, CEM, CDSM \\ National Renewable Energy Laboratory \\ Washington, DC
}

\begin{abstract}
A partnership among the Federal government, a utility, and water efficient equipment manufacturers was developed in response to the Executive Order 12902, Energy and Efficiency in Federal Facilities, where water conservation is still a fairly undeveloped part of resource conservation in the Federal government. The Department of Energy's Federal Energy Management Program (with the National Renewable Energy Laboratory) managed the project, bringing together the Environmental Protection Agency, General Services Administration and Bureau of Reclamation with Denver Water and four water use equipment manufacturers to install and test water-saving indoor and outdoor technologies at the Denver Federal Center. This paper will describe the process used to form this partnership and document the results and its potential impact.
\end{abstract}

\section{BACKGROUND}

With most of the water resource management activity taking place in states and local jurisdictions, why would the Federal government and, specifically, the Department of Energy (DOE), be interested in a water conservation project? The Federal Energy Management Program (FEMP) has been tasked with assisting Federal agencies to meet the Energy Policy Act of 1992 (EPACT) $^{1}$ and Executive Order $12902^{2}$ mandates to conserve water at Federal sites. Although Federal buildings are notoriously energy inefficient, the energy community has educated facility managers to the point where most understand where energy opportunities exist or at least know where to go for help in identifying them. In contrast, energy managers have been handed the responsibility of managing water but do not have the resources or expertise to identify water conservation opportunities nor to calculate water and energy savings attributable to those projects. Several concerned agencies--DOE's FEMP Program, the General Services Administration (GSA), the Bureau of Reclamation, and the Environmental Protection Agency (EPA)--decided to partner with Denver Water, the local utility, and several manufacturers to learn more about high-efficient water-use technologies. The site, Building 67 at the Denver Federal Center, was chosen because it represents a typical Federal office building, because it has high visibility in the community, and because it is in an area of the country where water efficiency is quickly becoming an economic issue.

\section{PROCESS}

Because water prices in Denver are relatively low, water savings alone could not justify an entire site or even building retrofit, nor would a water service company be interested in financing the project. A unique contractual mechanism exists in the Department of Energy laboratories--a Cooperative Research and Development Agreement (CRADA) ${ }^{3}$--which removes the need for standard competition and allows emerging technologies to be installed at no cost to the Federal government for the purpose of testing the equipment. A solicitation for the latest indoor and outdoor water use technologies was advertised in the Commerce Business Daily ${ }^{4}$ and sent to mailing lists of plumbing and landscape irrigation manufacturers. Technical proposals from United States manufacturers were submitted and technologies were selected based on appropriateness to the site and building, energy and water savings potential, and transferability to other Federal buildings. The three indoor technologies 
chosen were American Standard ultra low flush (ULF) wall-hung flushometer valve toilet ${ }^{5}$, Waterless Company's non-water-using urinal ${ }^{6}$, and Bradley's sensored lavatory system ${ }^{7}$. For landscape irrigation, the most effective technology was deemed to be WaterLink Systems, Inc. ${ }^{8}$ irrigation controls, because only a small acreage of land would be tested.

TABLE 1: Denver Federal Center CRADA Partners and Contributions

\begin{tabular}{|l|l|}
\hline PARTNERS & CONTRIBUTIONS \\
\hline Department of Energy--FEMP & Upper management, program support \\
\hline Nat'l Renewable Energy Lab & CRADA facilitation, technical support \\
\hline General Services Administration & Site management, labor support \\
\hline Bureau of Reclamation & User feedback, interpretive display \\
\hline Environmental Protection Agency & Modeling tool, environmental study \\
\hline Denver Water & Water audit, user satisfaction survey \\
\hline American Standard & Demonstration units for 6 restrooms \\
\hline Waterless Company & Demonstration units for 3 men's rooms \\
\hline Bradley Corporation & Demonstration units for 6 restrooms \\
\hline WaterLink Systems, Inc. & Controls for one landscaped acre \\
\hline
\end{tabular}

\section{MECHANISM}

In a CRADA, the manufacturers donate their technologies; the Federal government can use only in-kind, non-capital resources. In this project, only a select number of representative rest rooms and landscaped area were chosen so that manufacturers could statistically test their equipment without incurring a cost-prohibitive financial burden. Upper management of all partners agreed to the CRADA in January 1995, and contracting officers reached consensus in the summer 1995. A Joint Statement of Work appendix to the CRADA was the most critical part of the document, as it specified the roles and goals of the project. Each partner was given assignments and deliverables with a timetable and projected resource cost for each activity. The goal was for partners to share resources equally and in proportion to the benefit that they would each reap from the project.

\section{OBJECTIVES}

With a partnership of this type, although there may be objectives common to all partners, each partner has a specific reason for entering into the agreement. Goals common to all partners were the deployment of U.S. manufactured water technologies in the Federal sector (in hopes of stimulating widespread commercialization of these technologies), the improvement of energy and water efficiency in the Federal sector, the reduction of life-cycle cost and improved reliability of Federal installations, the documentation of ways Federal facility managers could effect change, and the demonstration that government and industry can work together to meet these common goals.

As facilitators of the CRADA and advocates of Federal water and energy efficiency, DOE and NREL wanted to secure the partnership and enable other Federal agencies to save water and costs by utilizing highly efficient water technologies and landscaping practices. The objectives of equipment and system manufacturers were to further document the capability of their products by installing them in a highly visible Federal building and having their performance objectively monitored. Denver Water, the utility serving the Federal Center, 
wanted to utilize their water supply more efficiently and test the application of long-term, sustainable water conservation methods that could then be applied to the rest of their customer base. GSA, as landlord of the Federal Center, wanted to establish a showcase site to demonstrate technologies and operating practices of water efficiency, which could serve as a model for other GSA-operated sites. The Bureau of Reclamation, as the building tenant, wanted to support water conservation efforts demonstrating by example the use of these technologies as well as presenting the success in their building through an interpretive display. EPA, as another partner and a firm advocate of resource conservation, wanted to reduce the environmental impact of Federal facilities through improved water use efficiency and to test their water management software ${ }^{9}$ for application to the Federal sector.

Technical objectives common to all partners were to successfully install and document the results of these devices and systems, to determine life-cycle cost savings that can be achieved through water conservation, to develop an interpretive display to educate others about these conservation measures, and to estimate the resource conservation and environmental benefits of a water-efficiency project.

\section{TECHNOLOGIES}

Because the building is a high-rise office space with wall-hung flushometer valve toilets and urinals, innovative technologies with tank-type toilets were ruled out. American Standard had just manufactured a wall-hung ULF (1.3 gallon per flush) unit and offered a number of demonstration porcelain and valves. Waterless urinals were fairly new and could save nearly all water used by conventional urinals. The Bradley lavatories would provide water as well as energy savings through reduced hot water use. Irrigation controls by WaterLink were estimated to be more important than a new irrigation system. The Denver Federal Center ground management group had already committed to apply Xeriscaping ${ }^{10}$ principles to new or refurbished turf areas, so a watering system seemed cost-prohibitive in the long run. The small amount of turf around Building 67 did not lend itself to installation of a new irrigation system. Controlling existing watering schedules seemed the most practical way to make a difference in outdoor use.

TABLE 2: Chosen Technologies, Manufacturers, and End Uses

\begin{tabular}{|l|l|l|}
\hline TECHNOLOGY & MANUFACTURER & END USE \\
\hline ULF Wall-Hung Toilet & American Standard & toilet--all test restrooms \\
\hline Non-water using urinal & Waterless Company & urinal--men's restrooms \\
\hline Sensored lavatory & Bradley Corporation & sink--all test restrooms \\
\hline Irrigation controls & WaterLink Systems, Inc. & outdoor landscaping \\
\hline
\end{tabular}

\section{TESTING}

To demonstrate the effectiveness of these technologies, all partners agreed that it would be critical to baseline existing water consumption at both the building and restroom use levels. Because meters were located only at two exterior site locations, a building meter had to be installed. An ultrasonic unit was chosen because the plumbing was configured in such a way that inhibited in-line metering. Meters were also installed to measure total use in a men's and a women's restroom. This usage was recorded and data were collected for approximately ten weeks. End use metering at a urinal, a toilet, and a sink could determine exactly what the end use of water would be in each restroom. The end-use meters were installed to record 4 weeks of usage prior to the new equipment installation.

Before installing the irrigation control system, the current system had to be adjusted-- head 
pressures modified, leaks repaired--so that the new system would be controlling a welloperated and maintained irrigation system. Because the Federal Center grounds were undergoing renovation and repaving, this effort was postponed until late summer to allow the irrigation system to be repaired. The new system would use a telephone line and modem connected to the manufacturer's office in California where the schedule would be controlled. The system was originally programmed based on a given watering schedule, then corrected using local weather data and periodic soil samples. These monitoring measures were critical in ensuring an accurate baseline of water use that could be used to calculate actual water savings achieved by the installed technologies.

\section{OUTCOMES}

In addition to metering, other testing of the technologies occurred. Occupant satisfaction and comfort with the new equipment had to be monitored. Signs were posted over the new equipment in the restrooms to alert users of the new technology designed to save water; users were also informed that the fixtures were being tested for widespread use. These signs asked that occupants be open-minded to change, but that they also be candid about reporting dissatisfaction or maintenance issues. In addition, service calls needed to be tracked to ensure that the equipment had been properly installed and that, once any new procedures were learned, it did not cost more in staff time to maintain than the existing equipment.

\section{RELATED BENEFITS}

Water savings and customer satisfaction were not the only expected outcomes of this initiative. Other benefits included energy savings directly related to the water use reduction-reduced waste-water treatment, reduced pumping, reduced hot water to be heated. Because urban run-off is the biggest source of urban water pollution, the irrigation control system was targeted to benefit the environment by causing less run-off of fertilizers into the ecosystem (due to less overwatering) and less solid waste of grass cuttings to be disposed of on the site (due to less mowings). Thus, although this project was technology and end-use based, consideration was given to the impact of these measures on other resources and the environment.

\section{LESSONS LEARNED}

One of the first lessons learned in this process was that, although having many partners could bring many rich and varied contributions, having ten partners agree upon one document is nearly impossible, especially in a short time. Much credit must be given to the attorneys and contracting officers for laboring and negotiating to ensure that all partners could live with the resulting document. Such a detailed study also required much coordination and took longer than expected because of difficulties acquiring meters, determining building baseline and repairing existing system inefficiencies.

\section{FUTURE}

This project is still not complete. The new technology monitoring must be completed and data must be analyzed. Cost-effectiveness must be calculated and interpreted. Environmental benefits must be quantified and documented. The challenge also remains to ensure that the lessons learned and the technologies demonstrated in this study are actually transferred to other Federal facilities. Dissemination efforts such as this paper and other publications will continue and will require constant follow-up to ensure that the time and resource investment made in this project will benefit other Federal energy and water managers. All partners agree that future projects should encompass more than technologies; they should include total water resource management plans and sustainability efforts to manage all resources and reduce site waste. The importance and groundbreaking nature of this project, however, should be built upon for even more effective and expansive work to reduce the cost of government. 


\section{ACKNOWLEDGEMENT}

I wish to thank the co-authors and partners in this ambitious undertaking: Liz Gardener of Denver Water, Steve Hochman and Debra Yap of GSA, Murl Coffey and Roy Amold of Bureau of Reclamation, John Flowers of EPA, Brian Brittsan of American Standard, Klaus Reichardt of Waterless, Kent Nichols of Bradley Corporation and Gary Gelinas of WaterLink Systems, Inc. Credit should be given to Ed Hancock of NREL and GSA facility operations staff at Denver Federal Center for spending much time and energy in monitoring the water use. Thanks are due as well to Christine Ervin, Assistant Secretary of Energy,

Mark Ginsberg, Director of the Federal Energy Management Program, Bill Marshall of National Renewable Energy Laboratory and Ed Osann of Bureau of Reclamation for their management support and willingness to take risks for this project. Thanks also to Ken Algiene for convincing more parties than thought possible to sign the agreement.

\section{ENDNOTES}

1. Energy Policy Act 1992 (EPACT)(P.L.102-486), Sec.152, Federal Energy Management Amendments.

2. Executive Order 12902, March 8, 1994, Energy Efficiency and Water Conservation in Federal Facilities.

3. Stevenson-Wydler (15 USC 3710) Cooperative Research and Development Agreement.

4. Commerce Business Daily announcement, Synopsis No.TT-108, April, 1994.

5. American Standard AFWALL ${ }^{\text {TM }}$ EL 1.6 Elongated Flush Valve Toilet.

6. Waterless NO-FLUSH ${ }^{\mathrm{TM}}$ Urinals, Model No. 2003 Kalahari $^{\mathrm{TM}}$.

7. Bradley Express ${ }^{\mathrm{TM}}$ Lavatory System, Models SS2 and SS3.

8. WaterLink System ${ }^{\mathrm{TM}}$ Outdoor Water Management Control System.

9. EPA's WAVE-Saver software designed for Water Alliances for Voluntary Efficiency Program to address water use in hotels.

10. Xeriscaping means the conservation of water and energy through creative landscaping; seven basic principles are applied when adopting Xeriscaping to any landscape. 